\title{
POSSIBILITIES OF MIRR METHOD APPLICATION FOR EVALUATION OF INVESTMENTS IN AGRICULTURE: AN EXAMPLE OF PIGS FATTENING ${ }^{1}$
}

\author{
Sanjin Ivanović2 ${ }^{2}$ Lana Nastić3 ${ }^{3}$ Bojana Bekić4
}

\begin{abstract}
In the case of some agricultural investments, often net cash flow changes its sign from positive to negative, many times during the project. It causes the problem of internal rate of return calculation, which is an important indicator of economic effectiveness of investments. That is, in such situations, internal rate of return cannot be used. To solve this problem, modified rate of return is applied. This paper aimed to describe this method in detail, and to show its calculation for investments in pigs fattening. By application of modified internal rate of return it is determined that pigs fattening, under assumed conditions, is economically justified. Also, authors calculated the upper limit of discount rate (cost of capital), to which investment in pigs fattening is economically justified. It is concluded that, in the case of specific agricultural investments (such as pigs fattening), the use of traditional internal rate of return could give the wrong image on actual rate of return on investments.
\end{abstract}

Key words: pigs fattening, IRR, MIRR, cost of capital.

JEL: $G 31, Q 12, Q 14$

1 Paper is a part of the research at the project no. III 46006 - Sustainable agriculture and rural development in the function of accomplishment of strategic goals of the Republic of Serbia within the Danube region, and project TR-31051 - Improvement of biotechnological procedures as a function of rational utilization of energy, agricultural products productivity and quality increase, financed by the Ministry of Education, Science and Technological Development of the Republic of Serbia, for the project period 2011-2014.

2 Sanjin Ivanović, Ph.D., Associate Professor, Faculty of Agriculture, Belgrade University, Nemanjina Street no. 6, 11080 Zemun, Serbia, Phone: +381 1126153 15/int. 426, E-mail: sanjinivanovic@agrif.bg.ac.rs

3 Lana Nastić, M.A., Research Associate, Institute of Agricultural Economics, Volgina Street no. 15, 11060 Belgrade, Serbia, Phone: +381 1169728 52, E-mail: lana n@iep.bg.ac.rs

4 Bojana Bekic, B.Sc., Research Associate, Institute of Agricultural Economics, Volgina Street no. 15, 11060 Belgrade, Serbia, Phone: +381 1169728 52, E-mail: bojana_b@iep.bg.ac.rs

EP 2015 (62) 2 (325-333) 


\section{Introduction}

Net cash flow of investments in agriculture can vary because of different reasons. Investments in agricultural production are a group of highly risky investments, because expected effects may greatly depend on environmental conditions, on which the investor cannot influence or this influence is limited. It refers mainly on investments in crop production, fruit production and viticulture, where impact of natural factors is highly expressed. However, risks of crop production are transferred to investments in livestock breeding trough fodder expenses. Besides risks caused by natural factors, in Serbia there are great risks related to changes of input prices or finished products. All of the above risks are reflected in variations of the amount of net cash flow received from investments. Other possible reasons of net cash flow variations in agriculture are biological characteristics of production process, which cannot be influenced on, or the influence of production manager is relatively small. The same consequences can also be caused by production process organization. Good example are various types of fattening (beef, pigs, broilers), where in different years, different number of animals are sold, so net cash flow greatly varies from one year to another (in some years it can be positive and in other negative).

These variations of net cash flow may have great impact on indicators of economic effectiveness of investments, especially Internal Rate of Return (IRR). Unlike Net Present Value (NPV), which is the absolute indicator of economic effectiveness of investments, IRR represents relative indicator (expressed in percent). While discount rate reflects minimal required interest rate of invested assets, IRR shows actual interest rate of invested assets. That is, IRR is a discount rate where NPV of investment is zero.

Evaluation of economic effectiveness of investments using IRR method is conducted by comparing discount rate and determined IRR. The rule is, if IRR is higher than discount rate than NPV of investment is positive, so investment is economically acceptable. That is, if IRR is higher than discount rate, than actual interest rate of invested assets is higher than cost of capital.

However, use of IRR is related to certain problems and objections, where the most important are:

- IRR method cannot be applied in cases where during investment use (except for initial cash outflow) the negative net cash flows appeared,

- Theoretical stand is questionable (as starting point when calculating internal rate of return) regarding reinvesting rate of net cash flow, released from the investment. The assumption is that reinvestment rate equals to IRR. More realistic assumption is that the reinvestment rate is equal to discount rate (Garrison et al., 2006).

Obviously, there are significant objections regarding the IRR method, which can lead to wrong results of investment analysis, and therefore to bad business decisions. First objection, that this method cannot be used if there are frequent changes of net cash flow from positive to negative, and vice versa, is based on the fact that then IRR loses its usability. Namely, then there are multiple solutions, that is several IRRs (Rosen, 1995). 
That is, exact number of IRRs depends on number of cash flow changes from positive to negative (Brealey, Myers, 2003).

Appearance of multiple solutions (IRRs) is caused by type of formula for calculation of the internal rate of return. It is polynomial, and therefore there are $n$ possible solutions. In the case of normal cash flow (which considers one initial cash outflow and later constant positive cash flows) all solutions, except one, are imaginary numbers. Of course, when there are multiple solutions, they have no practical importance and they should not be considered.

Aiming to solve the problem of multiple IRRs, some improvements of this method were introduced in economic theory, and that led to definition of Modified Internal Rate of Return (MIRR). This new method solved not only the problem of multiple IRRs, but also other major imperfection of IRR - unrealistic assumption about the reinvesting rate of net cash flow. Traditionally, when calculating IRR, it was assumed that net cash flow of investment was reinvested under the same rate of IRR. However, if IRR is too high, than it cannot be expected to reinvest net cash flow under such high interest rate. On the other hand, establishment of MIRR is based on the assumption that net cash flow is reinvested per costs of capital (the same case as calculating investment's NPV). It is considered that this new approach has significant advantage, in compare to the classical method of calculating IRR. Therefore it is a better indicator of actual rate of return of invested assets. This indicator gives lower rate of return than classical IRR, and cannot cause overestimation of rate of return. But MIRR method also has its disadvantages, such as determination of accurate reinvestment rate (Green, 1991).

Shim et al. (2008) emphasize that MIRR overcomes the disadvantage of IRR regarding of mutually exclusive projects. Fabozzi et al. (2008) explained that both IRR and MIRR ignore the scale of the investment. Therefore, in the case of mutually exclusive projects, they may lead to an incorrect decision. Cary and Dunn (1997) demonstrate how MIRR can be adjusted to give rankings of mutually exclusive projects that are consistent with NPV. Satyasai (2009) demonstrated application of modified IRR method coupled with adjustment for scale and time span differences using data for four watersheds. Mackevičius and Tomaševič (2010) discussed in detail specific technique for resolving NPV and IRR conflict. Rousse (2008) suggested possibilities for solution of some specific problems related to calculation of MIRR (issues connected to cost of capital and uncertainty).

Application of MIRR method for evaluation of investments in agriculture, in our conditions, was researched only by Ivanović (2008), Gogić (2011), Ivanović (2013), and Gogić and Ivanović (2013). MIRR method is almost ignored in significant and highly respected textbooks, and usually avoided by executives because it is considered difficult to understand and compute Kierulff (2008). Having in mind misuse of IRR in practice, it is needed to pedagogically emphasize the superiority of the NPV and MIRR decision rules (Balyeat et al., 2013).

Therefore this paper aims to present MIRR methodology in detail, to describe its advantages over IRR method, as well as the possibility of its application in agriculture. In that sense, an example of investing in pigs fattening is going to be used, because this production is known 
for cyclic changes of net cash flows. This topic is significant because it is impossible to use IRR methodology for investment valuation if net cash flow changes its sign from positive to negative multiple times.

\section{Material and Method}

In paper authors used model of family farm which invest in pigs fattening facility with capacity of 100 heads per production cycle. Fattening is done from $25 \mathrm{~kg}$ to $105 \mathrm{~kg}$ of weight. After that, pigs are sold at market. For the need of this analysis, authors used their internal documentation as well as STIPS database (System of Agricultural Market Information of Serbia). All cash inflows and outflows are calculated on the basis of market price. Feed used in pigs fattening is purchased on market. The most important elements of feed are corn and soybean meal. It is also supposed that family farm uses state subsidies for pigs fattening.

Calculation of MIRR will be done using formula of Brigham and Gapenski (1997). This formula is based on the assumption that negative cash flow appears not only at the beginning of investing process (once when investment facility is purchased), but also later during investment use:

$$
\sum_{t=0}^{n} \frac{C O F_{t}}{(1+k)^{t}}=\frac{\sum_{t=0}^{n} C I F_{t}(1+k)^{n-t}}{(1+M I R R)^{n}}
$$

Where: $C O F$ - cash outflows; $C I F$ - cash inflows; $k$ - cost of capital; $M I R R$ - modified internal rate of return; $n$ - years of investment use; and $t$-individual year of investment use.

Modified internal rate of return is defined as discount rate, which, as stated by Barry et al. (2000), equates present value of cash outflows with future value of cash inflows. Using MIRR it is important to remember that selection of the moment for which cash surplus will be discounted is of no relevance in only one case, i.e. when MIRR equals IRR (Merlo, 2013).

\section{Results and discussion}

Amount and structure of investments in pigs fattening are shown in Table 1, cash inflows, cash outflows and net cash flow are shown in Table 2. When calculating net cash flow, interest costs and depreciation were not included in cash outflow. It can be seen that net cash flow (in the moment of investing) is negative and also in the first, fourth and seventh year of investment use. That is why, for estimation of economic effectiveness of investments, MIRR must be used instead of IRR. 
POSSIBILITIES OF MIRR METHOD APPLICATION FOR EVALUATION OF INVESTMENTS IN AGRICULTURE: AN EXAMPLE OF PIGS FATTENING

Table 1. Amount and structure of investments in pigs fattening

\begin{tabular}{|l|r|r|}
\hline \multicolumn{1}{|c|}{ Item } & \multicolumn{1}{c|}{ Amount (EUR) } & \multicolumn{1}{c|}{ Structure (\%) } \\
\hline Buildings & $28,100.00$ & 62.90 \\
\hline Equipment & $5,600.00$ & 12.53 \\
\hline Working assets & $10,974.93$ & 24.57 \\
\hline Total & $\mathbf{4 4 , 6 7 4 . 9 3}$ & $\mathbf{1 0 0 . 0 0}$ \\
\hline
\end{tabular}

Source: Authors' calculation according to Ivanović, 2014; STIPS, 2014.

Table 2. Cash inflows, cash outflows and net cash flow (salvage value of investment is not included in last year), (EUR)

\begin{tabular}{|c|c|c|c|c|c|c|c|c|c|c|}
\hline \multirow{2}{*}{ Indicators } & \multicolumn{10}{|c|}{ Year } \\
\hline & 1 & 2 & 3 & 4 & 5 & 6 & 7 & 8 & 9 & 10 \\
\hline Cash inflows & $31,486.00$ & $47,229.00$ & $47,229.00$ & $31,486.00$ & $47,229.00$ & $47,229.00$ & $31,486.00$ & $47,229.00$ & $47,229.00$ & $47,229.00$ \\
\hline $\begin{array}{l}\text { Revenue from } \\
\text { sold pigs }\end{array}$ & $29,820.00$ & $44,730.00$ & $44,730.00$ & $29,820.00$ & $44,730.00$ & $44,730.00$ & $29,820.00$ & $44,730.00$ & $44,730.00$ & $44,730.00$ \\
\hline $\begin{array}{l}\text { Subsidies for pig } \\
\text { fattening }\end{array}$ & $1,666.00$ & $2,499.00$ & $2,499.00$ & $1,666.00$ & $2,499.00$ & $2,499.00$ & $1,666.00$ & $2,499.00$ & $2,499.00$ & $2,499.00$ \\
\hline Cash outflows & $33,963.83$ & $34,709.33$ & $30,134.33$ & $33,963.83$ & $34,709.33$ & $30,134.33$ & $33,963.83$ & $34,709.33$ & $30,134.33$ & $34,709.33$ \\
\hline Fodder costs & $14,721.58$ & $14,721.58$ & $14,721.58$ & $14,721.58$ & $14,721.58$ & $14,721.58$ & $14,721.58$ & $14,721.58$ & $14,721.58$ & $14,721.58$ \\
\hline Water & 46.00 & 46.00 & 46.00 & 46.00 & 46.00 & 46.00 & 46.00 & 46.00 & 46.00 & 46.00 \\
\hline Piglets & $13,725.00$ & $13,725.00$ & $9,150.00$ & $13,725.00$ & $13,725.00$ & $9,150.00$ & $13,725.00$ & $13,725.00$ & $9,150.00$ & $13,725.00$ \\
\hline $\begin{array}{l}\text { Veterinarian } \\
\text { services }\end{array}$ & $1,350.00$ & $1,350.00$ & $1,350.00$ & $1,350.00$ & $1,350.00$ & $1,350.00$ & $1,350.00$ & $1,350.00$ & $1,350.00$ & $1,350.00$ \\
\hline Electricity & 104.00 & 104.00 & 104.00 & 104.00 & 104.00 & 104.00 & 104.00 & 104.00 & 104.00 & 104.00 \\
\hline $\begin{array}{l}\text { Maintenance of } \\
\text { buildings }\end{array}$ & 70.25 & 70.25 & 70.25 & 70.25 & 70.25 & 70.25 & 70.25 & 70.25 & 70.25 & 70.25 \\
\hline $\begin{array}{l}\text { Maintenance of } \\
\text { equipment }\end{array}$ & 56.00 & 56.00 & 56.00 & 56.00 & 56.00 & 56.00 & 56.00 & 56.00 & 56.00 & 56.00 \\
\hline $\begin{array}{l}\text { Insurance for pigs } \\
\text { fattening }\end{array}$ & $1,491.00$ & $2,236.50$ & $2,236.50$ & $1,491.00$ & $2,236.50$ & $2,236.50$ & $1,491.00$ & $2,236.50$ & $2,236.50$ & $2,236.50$ \\
\hline Labor & $2,400.00$ & $2,400.00$ & $2,400.00$ & $2,400.00$ & $2,400.00$ & $2,400.00$ & $2,400.00$ & $2,400.00$ & $2,400.00$ & $2,400.00$ \\
\hline Net cash flow & $-2,477.83$ & $12,519.68$ & $17,094.68$ & $-2,477.83$ & $12,519.68$ & $17,094.68$ & $-2,477.83$ & $12,519.68$ & $17,094.68$ & $12,519.68$ \\
\hline
\end{tabular}

Source: Authors' calculation according to Ivanović, 2014; STIPS, 2014.

To determine NPV of this investment (Table 3) authors used net cash flow from Table 2 and discount rate of $8 \%$ that is formed in model as weighted average cost of capital (WACC). Considering that NPV is positive, this investment is economically acceptable.

Table 3.Calculation of NPV in pigs fattening

\begin{tabular}{|c|r|c|r|}
\hline Year & Net cash flow (EUR) & Discount factor (8\%) & Discounted NCF (EUR) \\
\hline 0 & $44,674.93^{*}$ & 1.0000 & $-44,674.93$ \\
\hline 1 & $-2,477.83$ & 0.9259 & $-2,294.28$ \\
\hline 2 & $12,519.68$ & 0.8573 & $10,733.60$ \\
\hline 3 & $17,094.68$ & 0.7938 & $13,570.30$ \\
\hline 4 & $-2,477.83$ & 0.7350 & $-1,821.28$ \\
\hline 5 & $12,519.68$ & 0.6806 & $8,520.68$ \\
\hline 6 & $17,094.68$ & 0.6302 & $10,772.54$ \\
\hline
\end{tabular}




\begin{tabular}{|c|r|c|r|}
\hline Year & Net cash flow (EUR) & Discount factor (8\%) & Discounted NCF (EUR) \\
\hline 7 & $-2,477.83$ & 0.5835 & $-1,445.79$ \\
\hline 8 & $12,519.68$ & 0.5403 & $6,763.99$ \\
\hline 9 & $17,094.68$ & 0.5002 & $8,551.59$ \\
\hline 10 & $44,569.61 * *$ & 0.4632 & $20,644.35$ \\
\hline Net present value & & & $\mathbf{2 9 , 3 2 0 . 7 9}$ \\
\hline
\end{tabular}

Source: Authors' calculation according to Ivanović, 2014.

Note: *Initial cash outflow, ** Includes net cash flow and salvage value of investment.

Entire process of calculation of MIRR (Table 4) begins by discounting of cash outflows at the moment of investing (moment of initial cash outflow creation). It is done by discount rate application, calculated on the basis of costs of capital. On the other hand, determination of total future value of cash inflows is done, assuming that inflows are reinvested at the cost of capital (Brigham and Gapenski, 1997).

Table 4. Calculation of MIRR

\begin{tabular}{|c|c|c|c|c|c|}
\hline \multirow[b]{2}{*}{ Year } & \multirow[b]{2}{*}{$\begin{array}{l}\text { Net cash flow } \\
\text { (EUR) }\end{array}$} & \multicolumn{2}{|c|}{ Discounting } & \multicolumn{2}{|c|}{ Compounding } \\
\hline & & $\begin{array}{c}\text { Discount } \\
\text { factor }(8 \%)\end{array}$ & $\begin{array}{l}\text { Discounted negative } \\
\text { cash flow }\end{array}$ & $\begin{array}{l}\text { Compounding } \\
\text { factor }(8 \%)\end{array}$ & $\begin{array}{c}\text { Compounded } \\
\text { positive cash flow }\end{array}$ \\
\hline 0 & $-44,674.93$ & 1.0000 & $44,674.93$ & 2.1589 & \\
\hline 1 & $-2,477.83$ & 0.9259 & $2,294.28$ & 1.9990 & \\
\hline 2 & $12,519.68$ & 0.8573 & & 1.8509 & $23,173.04$ \\
\hline 3 & $17,094.68$ & 0.7938 & & 1.7138 & $29,297.27$ \\
\hline 4 & $-2,477.83$ & 0.7350 & $1,821.28$ & 1.5869 & \\
\hline 5 & $12,519.68$ & 0.6806 & & 1.4693 & $18,395.51$ \\
\hline 6 & $17,094.68$ & 0.6302 & & 1.3605 & $23,257.12$ \\
\hline 7 & $-2,477.83$ & 0.5835 & $1,445.79$ & 1.2597 & \\
\hline 8 & $12,519.68$ & 0.5403 & & 1.1664 & $14,602.95$ \\
\hline 9 & $17,094.68$ & 0.5002 & & 1.0800 & $18,462.25$ \\
\hline 10 & $44,569.61$ & 0.4632 & & 1.0000 & $44,569.61$ \\
\hline Total & & & $50,236.28$ & & $171,757.74$ \\
\hline
\end{tabular}

Source: Authors' calculation according to Ivanović, 2014.

By application of approximate interest rates and linear interpolation, it is determined that MIRR is $13.08 \%$. That is, as stated by Peterson and Fabozzi (2002), MIRR is a return on the investment, assuming a particular return on the reinvestment of cash flows. Having in mind that MIRR is higher than cost of capital $(8 \%)$ this means that the investment is expected to return more than required, and should be accepted.

In this analysis cost of capital (8\%) is determined as WACC. It was assumed that equity opportunity cost is $4 \%$ while interest rate for loan is $12 \%$ (investment is financed $50 \%$ by equity and $50 \%$ by loan). It is important for MIRR that its height depends on height of cost of capital. Therefore MIRR will defer if the investment is financed only by equity or by loan (Table 5). 
Table 5. MIRR for various costs of capital

\begin{tabular}{|c|c|c|}
\hline Cost of capital & Modified internal rate of return & Net present value (EUR) \\
\hline $4 \%$ & $11.43 \%$ & $50,782.35$ \\
\hline $8 \%$ & $13.08 \%$ & $29,320.79$ \\
\hline $12 \%$ & $14.80 \%$ & $13,901.35$ \\
\hline $16 \%$ & $16.60 \%$ & $2,594.07$ \\
\hline $17 \%$ & $17.06 \%$ & 251.55 \\
\hline $18 \%$ & $17.52 \%$ & $-1,929.54$ \\
\hline
\end{tabular}

Source: Authors' calculation according to Ivanović, 2014.

It is obvious that investment in pigs fattening is economically acceptable for all assumed financing methods (between 4\% and 12\%). The investment would be economically unprofitable only if cost of capital is higher than $17 \%$. On the other hand, it is necessary to conduct additional analysis to check weather investment is financially feasible or not.

\section{Conclusion}

MIRR method is not sufficiently present in academic papers and in practice. Therefore it is necessary to pedagogically emphasize the superiority of this method over IRR method. Primarily MIRR method should be used for evaluation of projects with cash flows which could lead to multiple IRRs, which is common in agriculture. An example of analysis of economic effectiveness of investment in pigs fattening showed that this investment is economically acceptable, because MIRR (13.08\%) was higher than cost of capital ( $8 \%)$. Besides, changes of MIRR, for various amounts of costs of capital, were determined. The investment in pigs fattening is profitable if discount rate (cost of capital) is not higher than $17 \%$.

\section{References}

1. Balyeat, R. B., Cagle, J., Glasgo, P. (2013): Teaching MIRR to Improve Comprehension of Investment Performance Evaluation Techniques, Journal of Economics and Finance Education, vol. 12, no. 1, pp. 39-50.

2. Barry, J. P., Ellinger, N. P., Hopkin, A. J., Baker, B. C. (2000): Financial Management in Agriculture, Sixth Edition, Interstate Publishers Inc. Danville, Illinois, USA.

3. Brealey, R. A., Myers, S. C. (2003): Capital Investment and Valuation, McGraw-Hill, NY, USA.

4. Brigham, F. E., Gapenski, L. C. (1997): Financial Management-Theory and Practice, Eight Edition, the Dryden Press, NY, USA.

5. Cary, D., Dunn, M. (1997): Adjustment of Modified Internal Rate of Return for Scale and Time Span Differences, Allied Academies International Conference, Proceedings of the Academy of Accounting and Financial Studies, vol. 2, no. 2, Maui, Hawaii, pp. 57-63.

6. Fabozzi, F. J., Drake, P. P., Polimeni, R. S. (2008): The Complete CFO Handbook: From Accounting to Accountability, John Wiley \& Sons, NY, USA.

EP 2015 (62) 2 (325-333) 
7. Garrison, R. H., Noreen, E. W., Brewer, P. C. (2006): Managerial Accounting, Eleventh Edition, McGraw-Hill/Irwin, Boston, USA.

8. Gogić, P. (2011): Ekonomska efektivnost investiranja u hidromelioracije, Monograph, University in Belgrade, Faculty of Agriculture, Belgrade.

9. Gogić, P., Ivanović, S. (2013): Economics and Financial Analysis of Investments in Raspberry Plantations, Proceedings of the seminar: Agriculture and Rural Development Challenges of Transition and Integration Processes, University of Belgrade, Faculty of Agriculture, Department of Agricultural Economics, September, 27 $7^{\text {th }} 2013$, Belgrade, pp. 1-11.

10.Green, M. G. (1991): A standard method of property performance measurement, Investment Analysts Journal, spring 1991, pp. 7-19, available at: http:/www.iassa. co.za/articles/034_spr1991_01.pdf

11. Ivanović, S. (2008): Ekonomska efektivnost investicija u govedarskoj proizvodnji porodičnih gazdinstava, $\mathrm{PhD}$. Thesis, University in Belgrade, Faculty of Agriculture, Belgrade.

12. Ivanović, S. (2013): Analiza investicija u stočarskoj proizvodnji, Monograph, University in Belgrade, Faculty of Agriculture, Belgrade.

13. Ivanović, S. (2014): Documentation on costs and investments in pigs fattening, Internal unpublished documentation of author, Belgrade.

14. Kierulff, H. (2008): MIRR: A better measure, Business Horizons, vol. 51, no. 4, pp. 321-329.

15. Mackevičius, J., Tomaševič, V. (2010): Evaluation of Investment Projects in Case of Conflict between the Internal Rate of Return and the Net Present Value Methods, Ekonomika, vol. 89, no. 4, pp. 116-130.

16. Merło, P. (2013): Implications of discounting methods and relations between NPV, IRR and MIRR for efficiency evaluation of investment projects, Humanities and Social Sciences, vol. XVIII, no. 20(3), pp.103-117.

17.Peterson, P. P., Fabozzi, F. J. (2002): Capital Budgeting: Theory and Practice, John Wiley \& Sons, NY, USA.

18. Rosen, L. R. (1995): Handbook of Interest, Yields, and Returns, McGraw-Hill Inc., NY, USA.

19. Rousse, O. (2008): On the bias of yield-based capital budgeting methods, Economics Bulletin, vol. 7, no. 9, pp. 1-8.

20. Satyasai, K. J. S. (2009): Application of Modified Internal Rate of Return Method for Watershed Evaluation, Agricultural Economics Research Review, no. 22, pp. 401-406.

21.Shim, J. K., Siegel, J. G., Dauber, N. (2008): Corporate Controller's Handbook of Financial Management, CCH a Walters Kluwer Business.

22. STIPS (2014), database of System of Agricultural Market Information of Serbia, STIPS, 
Ministry of Agriculture and Environmental Protection of the Republic of Serbia, Belgrade, available at: http://www.stips.minpolj.gov.rs/, accessed at: October 2014.

\title{
MOGUĆNOSTI PRIMENE MIRR METODA ZA OCENU INVESTICIJA U POLJOPRIVREDI: PRIMER TOVA SVINJA
}

\author{
Sanjin Ivanovićs, Lana Nastićc ${ }^{6}$ Bojana Bekić7
}

\begin{abstract}
Kod nekih investicija u poljoprivredi često se javlja situacija da neto novčani tok menja svoj znak iz pozitivnog u negativni više puta u toku trajanja projekta. To izaziva problem izračunavanja interne kamatne stope, koja je važan indikator ekonomske efektivnosti investicija. Odnosno, u takvim uslovima se interna kamatna stopa ne može koristiti. Da bi se rešio taj problem primenjuje se modifikovana interna kamatna stopa. Cilj ovog rada je da se detaljno opiše ova metoda i prikaže njen način izračunavanja kod investicije u tov svinja. Primenom modifikovane interne kamatne stope utvrđeno je da je tov svinja pod pretpostavljenim uslovima ekonomski opravdan. Takođe je izračunata i gornja granica diskontne stope (troškova kapitala) do koje je investicija u tov svinja ekonomski opravdana. Zaključenoje da kod specifičnih investicija u poljoprivredi (kao što je to tov svinja) upotreba tradicionalne interne kamatne stope može pružiti pogrešnu sliku o stvarnoj stopi povraćaja na investiciona ulaganja.
\end{abstract}

Ključne reči: tov svinja, interna kamatna stopa, modifikovana interna kamatna stopa, diskontna stopa

5 Prof. dr Sanjin Ivanović, vanredni profesor, Poljoprivredni fakultet, Univerzitet u Beogradu, Nemanjina 6, 11080 Zemun, Srbija, Telefon: +381 1126153 15/lokal 426, E-mail: sanjinivanovic@agrif.bg.ac.rs

6 Lana Nastić, M.A., istraživač saradnik, Institut za ekonomiku poljoprivrede, Volgina 15, 11060 Beograd, Srbija, Telefon: +381 1169728 52, E-mail: lana n@iep.bg.ac.rs

7 Bojana Bekic, B.Sc., istraživač saradnik, Institut za ekonomiku poljoprivrede, Volgina 15, 11060 Beograd, Srbija, Telefon: +381 1169728 52, E-mail: bojana_b@iep.bg.ac.rs

EP 2015 (62) 2 (325-333) 